\title{
ASSESMENT OF THE BENEFITS OF CORPORATE SOCIAL RESPONSIBILITY REPORTS AS ONE OF THE MARKETING TOOLS
}

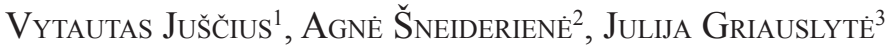 \\ Klaipèda University (Lithuania)
}

\begin{abstract}
This paper examines what benefits business can achieve by implementing corporate social responsibility reports in its activities. There are also analyzed the evolution of CSR reporting, systemized theoretical aspects of CSR reporting in marketing field. The article emphasized that then satisfying stakeholders' expectations, needs, and informing them of the action taken to meet these expectations, the organization have greater success of the business, i.e. stability and profitability. Literary analysis showed that CSR reporting is becoming the main tool of linking different holistic marketing programs.

KEYWORDS: corporate social responsibility, stakeholders, corporate social responsibility reports, holistic marketing, communication.
\end{abstract}

JEL CODES: M140, M310.

\section{Introduction}

Corporate Social Responsibility Reporting is increasingly becoming the subject of research in the scientific literature of developed countries scientists. There are analyzed the application of CSR reporting when developing the reputation and image of business (Adams, 2008), meeting the expectations of stakeholders needs and expectations (Jones et al, 2007); thus, it is important for business in shaping a competitive advantage. Moreover, there are analyzed the handling of CSR reporting when creating brand value (O'Rourke, 2004). On the other hand, some scientists in their papers try to prove that the reporting and publishing on CSR activities not necessarily has positive impact on business (Maignan, 2001; Jones et al., 2006) and stakeholders groups have not demand for achieving plenty of information about the social responsibility of business (Pelsmacker et al, 2005).

The major achievements analyzing, exploring the reports of CSR and their application possibilities belongs to the scientists of the United Kingdom (O'Connor, 2001; Idowu, 2004, 2007, 2011; Jones, Comfort, Hillier, 2005, 2006, 2007; Crowther, 2008; Birth, 2008; Samy, Odemilin, Bampton; 2010; Barthorpe, 2010; Walker, Jones, 2012).

1 Vytautas Juščius - Klaipėda University, Professor and Head of Economics Department. Scientifically fields: corporate social responsibility, globalization

E-mail: ek.smf@ku.lt

Tel.: +370 46398667

2 Agnè Šneideriené - Klaipèda University, Assistant of Economics Department. Scientifically fields: corporate social responsibility, regional development.

E-mail: a.sneideriene@yahoo.com

Tel.: +37046398667

3 Julija Griauslytè - AB "Klaipèda Water", economist. Scientifically fields: corporate social fields E-mail: julija.griauslyte@gmail.com Tel.: +37046398667 
Relevant topic of CSR reports in marketing does not adequate reflects in the papers of Lithuanians scientists. Unfortunately, studies on this topic have been carried out only in the context of other research facilities. Only few Lithuanian scientists (Dagilienè, Gokienė, 2011; Juščius, 2009; Žičkienė, Juozaitienė, 2013) at some extent analyze these reports.

Research problem - poor degree of testing the reporting of CSR activities in marketing.

Research object - the reports of CSR.

The aim of the article - to evaluate the benefits of the CSR reports as one of the marketing tool.

Research goals:

1. To analyze the evolution of CSR reporting.

2. To analyze and systemize the theoretical aspects of the application of CSR reports in marketing.

Methods: literature analysis and synthesis, systematization, content analysis.

\section{The evolution of the reporting on corporate social responsibility}

Corporate social responsibility is becoming increasingly important. Plethora of definitions, tools and a wide variety of adoption spheres, the growing influence of CSR in business and public decisions, prompted interest in this good business practice. According to P. Jones et al. (2007: 583), CSR is an important element of strategic management in helping companies to respond to the changes of business environment. For this purpose, it is useful for companies to prepare reports not only on financial outcomes but also on socially responsible activities. While attempts to publish occasional reports on the company's other activities rather than financial performance were before, but much more systematic and standardized CSR reporting occurs only at the end of 9 decade.

Development of CSR reporting periods were examined by Jones et al. (2007), S. O. Idowu, B. A. Towler (2004), the reasons and benefits for reporting were analyzed by D. O'Rourke (2004), S. O. Idowu and I. Papasolomou (2007), S. O. Idowu, B. A. Towler (2004), Y. Gao (2009), B. A. Towler (2007), L. Sweeney (2008), D. L. Gill et al. (2008).

According to P. Jones et al. (2007: 583), A. Marlin and J. T. Merlin divided the periods of development of the CSR reporting into three stages (Fig. 1). The first phase, which began about 1970, marked by promotions and accountability, focused on environmental issues, but in fact it had no connection with the company's activities. The first reports appeared only at the beginning of the second stage. At the second phase, which started in 1980, there appeared initiatives to asses the companies' activities in the field of corporate social responsibility; there are examined how companies takes into account the interest of the public, employees, customers, suppliers and investors. The third phase, which began in 1990, demonstrates the growing integration of social audit (assessment of social issues), environmental issues and certified standards to the companies' reports.

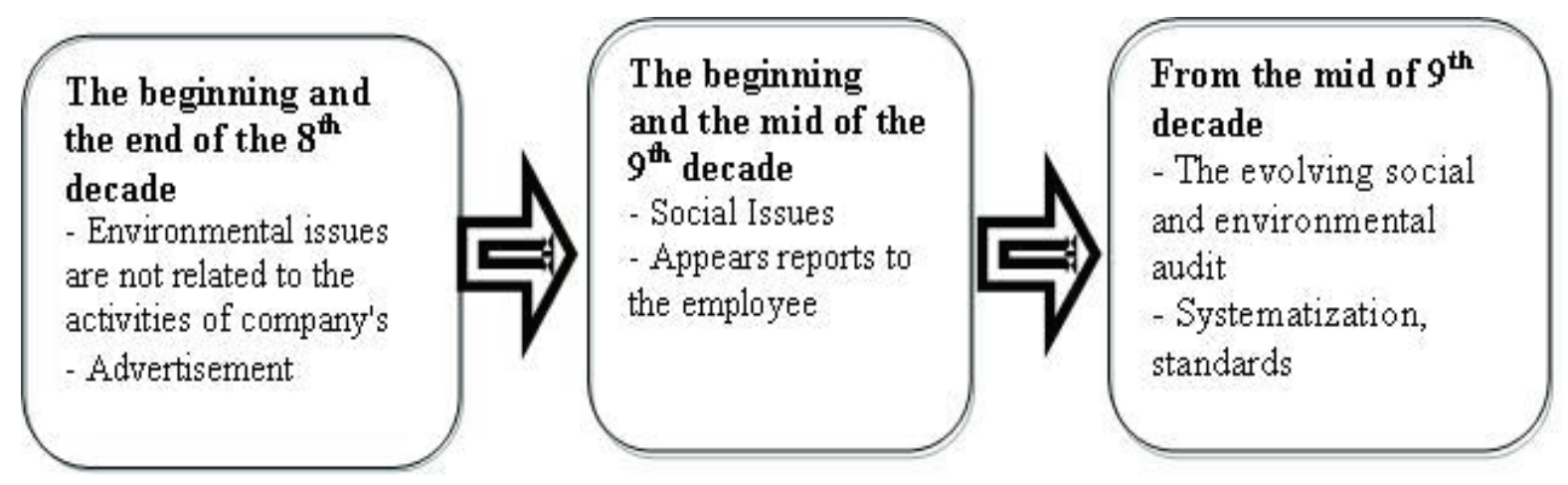

Figure1. The stages of CSR reporting development

Sources: composed by authors, according to Jones et al., 2007: 583 
Historically established fact that socially responsible business first took care of the needs of workers, led to that the first CSR reports were devoted to this stakeholder group. The first voluntary reports were prepared free form, were not regulated. In these reports, the companies made some graphs, charts, in order to inform employees on the main events that have occurred over the past 12 months (Idowu, Towler, 2004: 421).

On the second half of the $9^{\text {th }}$ decade, business, in connection with such events as the chemical disaster in India or an oil spill in Alaska, was pressed to take more social responsibility to its activities. In 1986, The U.S. Congress passed the "Energy Planning and Community Right-To-Know Act", in which were required for organizations to publish information about the emissions of toxic materials. Due to attempts of governments, businesses and non governmental organizations there have been developed a sufficiently broad range of CSR reporting system.

It can be argued that there are two main reasons that led the growing CSR reporting scale (see Figure 2 ). The first reason is the increasing pressures of various stakeholders' groups, and the second - corporate awareness that the public information on the implemented social and environmental initiatives is good for business.

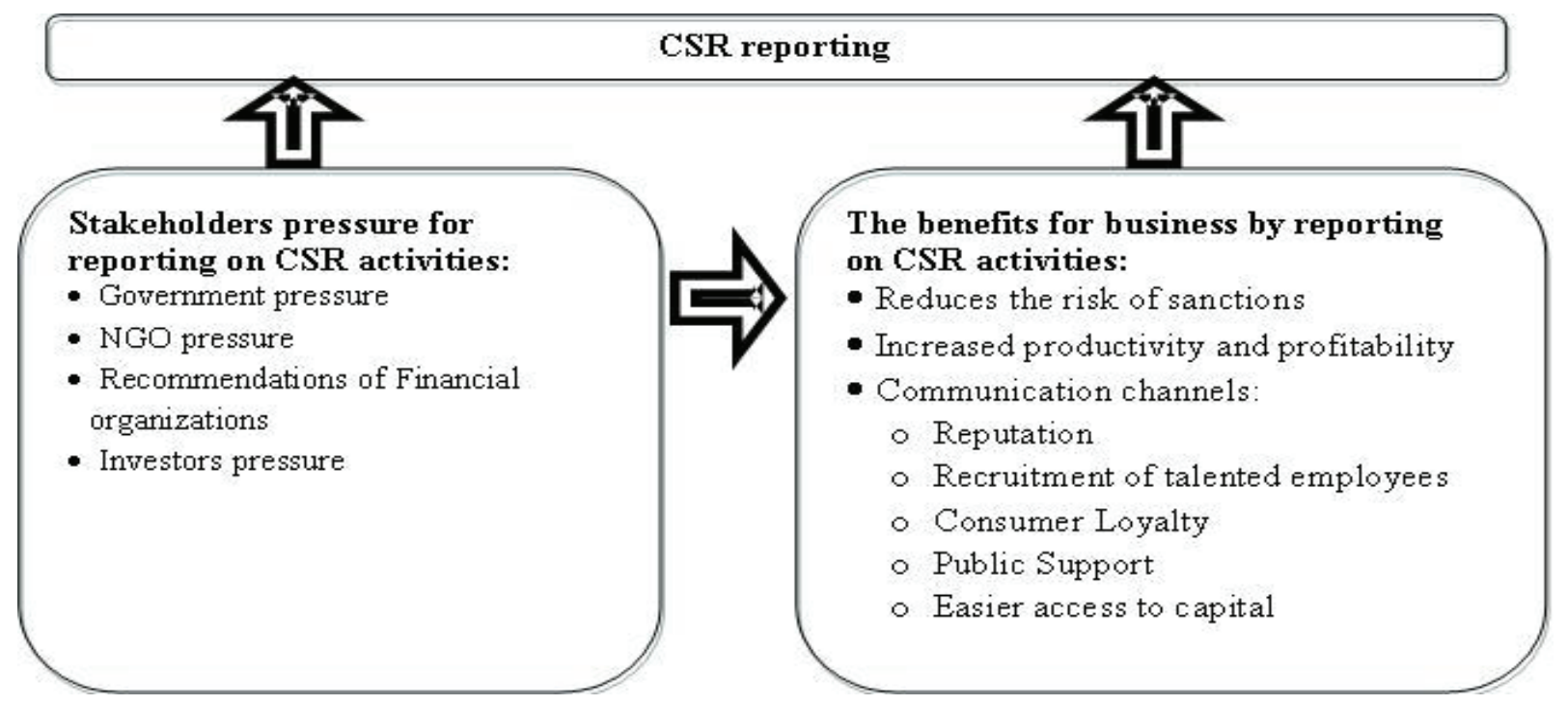

Figure 2. The considerations of CSR reporting

Source: composed by authors

According to S. O. Idowu and B. A. Towler (2004: 422), one of the main reasons for CSR reporting is the stakeholders right to know about the company's contribution to the creation of the public welfare. D. O'Rourke (2004) notes that public demand for comprehensive information is increasing every year. Meanwhile, S. O. Idowu and I. Papasolomou (2007: 139) argue that at the twenty-first century, the stakeholders groups are much more educated and before investing or issuing money, they want to know how responsible the organization is.

Although the first CSR report was voluntary, but still today in some countries there are attempting to implement the requirements for CSR reporting. The European Union has adopted a "European Modernization Directive", which encourages Member States to develop a legal framework for requiring accountability of the business made decisions relating to labor law and environmental protection. This Directive is implemented in the United Kingdom and Denmark, where companies are required to provide regular information on the CSR activities using standardized form. In the Great Britain on the basis of "European Modernization Directive" was implemented "Operating and financial review regulation"; there were due for companies to prepare CSR reports on fixed cases. According to O. Delbard (2008: 399), CSR reporting is mandatory in other Nordic and Western European countries: Finland, Sweden, Belgium, Holland and Germany. A. Douglas et al. (2004: 389) state out that there was conducted a comparative analysis of CSR reporting 
of companies in six European countries - United Kingdom, the Netherlands, Sweden, Switzerland, France and Germany and a comparative analysis of CSR reports. The study showed that the best practices of CSR reporting have German companies.

Non-governmental organizations, such as Green Pease, Amnesty International, and World Wide Fund also put pressure on businesses for CSR reporting. Y. Gao (2009: 265) argues that non-governmental organizations represent quite a lot of different interests (human rights, children's rights, labour, trade, the environment and society), so they can influence business.

Business also feels the pressure to publish information about the CSR initiatives from such financial organizations as stock exchanges and rating agencies. In some countries, one of the requirements for companies willing to trade their shares on the stock exchange is to prepare CSR reports. Y. Gao (2009: 265) provides an example the Paris Stock Exchange. Companies listed in this stock exchange must provide information not only about the economic results, but also about social and environmental performance in their financial statements. The Johannesburg Stock Exchange also applies such requirements. In United Kingdom, these requirements are applied not for all companies listed on the Stock Exchange, but only for companies of certain size and sector. S. O. Idowu and B. A. Towler (2004: 138) claim that $80 \%$ of the 100 largest UK companies, whose shares are quoted on the Financial Times Stock Exchange, prepare CSR reports. The Association of British Insurers developed the guidance, where was specified what king of information on social, environmental and ethical issues institutional investors expect to receive from the companies, whose shares are traded on the stock exchange, reports. Analogous recommendations have appeared in Lithuania. In 2012, there have been developed "Corporate social responsibility guidelines for companies listed in Stock Exchange".

Rating agencies, also encourage companies, especially those in the Down Jones Sustainability Index, Community's Corporate Responsibility Index and FTSE4 Good Index, to publish CSR reports, whereas in these indexes invest banks, insurance companies, investment funds. Companies must provide information on current CSR initiatives also for their investors and shareholders. Investors and shareholders wish to obtain the complete information, also about the non-financial risks and liabilities. D. O'Rourke (2004: 9) points out that in the financial markets there is growing interest on CSR reports and the growing demand for CSR investments. "In 2000 group of investors that manage property worth 140 billion dollars, sent the letters to the corporate leaders of the 500 largest U.S. companies insistently proposing to publish information on CSR in accordance with the Global Accountability Initiative (hereinafter referred to as GRI) guidelines (O'Rourke, 2004: 9). The increasing demand for CSR investment and CSR reporting also is witnessed by statistics. The data stated in the United Nations Development Programmes "Socially responsible investment" shows that the CSR investment market value at the end of 2009 amounted to $€ 5$ trillion, while in 2002 was less than 0.5 trillion euros (O'Rourke, 2012: 8).

D. O'Rourke (2004: 11) when analyzing non-voluntary CSR reporting when business is pressed or obliged by law to publish information on CSR, provides an interesting observation. He argues that financial and environmental reports are much more advanced than ones of social efficiency. The first requirements relating to CSR reporting, arises in financial reporting in order to provide detailed information for investors about the company's environmental commitment, risks and costs arising from non-compliance environmental or other law requirements; and those which can affect the company's profits. Requirements on CSR reporting in environmental protection legislation begin to capture after the appearance of "Pollutant Release and Transfer Registers". Such legislation firstly appeared in the United States in 1986 (U.S. Toxic Release Inventory), in Canada in 1993 (Canadian National Release Inventory), and in Mexico in 1996 (Mexican Registro de Emisiones y Transferencia de contaminants). In these documents there are required for companies to publish detailed information about the chemical species, quantity and location of emissions which fall in the nature. "Pollutant Release and Transfer Registers" success in North America led to the spread of this practice in other continents. In 2001 the European Commission adopted the "Convention on Access to Information, Public Participation in Decision Making, and Access to Justice in Environmental Matters". In developing countries were there also attempts to integrate the requirements of CSR reporting in the envi- 
ronmental protection laws. For example, in 1995 Indonesian Environmental Protection Agency established pollution reporting system - PROPER. Although the firsts CSR reports informed about social problems, but the integration of the CSR reporting requirements into the social legislation is the least developed. Belgium, the first in the world, established social accountability requirements in the legal system established.

Although the firsts CSR reports were voluntary, in the absence of legislation, but today the companies are under the great pressure from the public to provide information on CSR activities. With the growing interest in CSR, companies also realize the benefits of CSR reporting. However, the benefits of CSR reporting depend on the company's contribution. Only responsibly and professionally prepared reports can act as a powerful marketing tool and a means of helping to adapt CSR practice in marketing processes.

\section{The analysis of the corporate social responsibility reporting benefits} to business entities

Most of the authors (Idowu, Towler, 2004; O'Rourke, 2004; Sweeney, 2008; Gill, Dickinson, Scharly, 2008) note that in the twenty-first century, more and more companies realize the benefits of CSR reporting for business and voluntarily publish information about current CSR initiatives.

Growing the managers' perception that long-term corporate existence and success depends not only on the business but also on the environment in which it operates as well, CSR has become an integral part of the marketing strategy. This led to the changes of the marketing definition. In 2004, American Marketing Association has added the stakeholders groups to the definition of marketing. Thus, the basis of marketing process becomes a ability to create value by identifying and satisfying stakeholder expectations and needs. One of these needs is to get information about the social and environmental initiatives of business. I. Maignan et al (2005: 973) stated that it is likely that stakeholders will support CSR initiatives if they have the opportunity to know about the steps taken by the business in creating a common value.

It can be seen from the scientific literature analysis (Tewari, 2011; Sutanoputra, 2008; Hildebrand et al, 2011; O'Connor, 2001; Maignan, 2005; Sweeney, 2008) that CSR reporting is not only a tool of social responsibility, but is also an integrated, internal relations and marketing tool (see Figure 3). In the case of integrated marketing, the company, through CSR reports, may increase opportunities to create value, inform about it and represent it to stakeholders. In particular, companies use CSR reporting as a tool of communication with stakeholders. R. Tewari (2011: 24) argues that the essence of CSR communication is to create and maintain mutually beneficial relationships with the environment in which the business operates. "Regard to communication, companies can develop a positive public image" (Sutanoputra, 2008: 13). C. A. Adams (2008: 366) argues that companies try to enhance their reputation through CSR reporting (which is one of the image management forms). D. Hildebrand et al (2011: 1356) also claims that the company's communication, which is a set of association arising from stakeholders about company, affects its reputation. N. O'Connor (2001: 53) notes that the strong company's reputation increases its opportunities to expand into new markets, to attract the best employees, suppliers, business partners and investors, to create higher value products and services, protect the business from the crisis.

Meanwhile, L. Sweeney et al. (2008: 116) identify the reports of CSR as one of the communication channels. Due to communication increases customer loyalty, expands the part of public supporting the company, it is easier to recruit talented employees and decreases the risk of reputation.

CSR reporting is also associated with increasing productivity and profitability, and minimized risk. D. O'Rourke (2004: 9) complements this argument by claiming that CSR reports can serve as a self-regulatory instrument, which helps to avoid the risk in the future, because the problems are managed immediately after adoption. For example, if the company's goal is to reduce energy and water consumption, but reports suggest that company fails to implement this issue, then it is necessary to review the effectiveness of internal operations. 


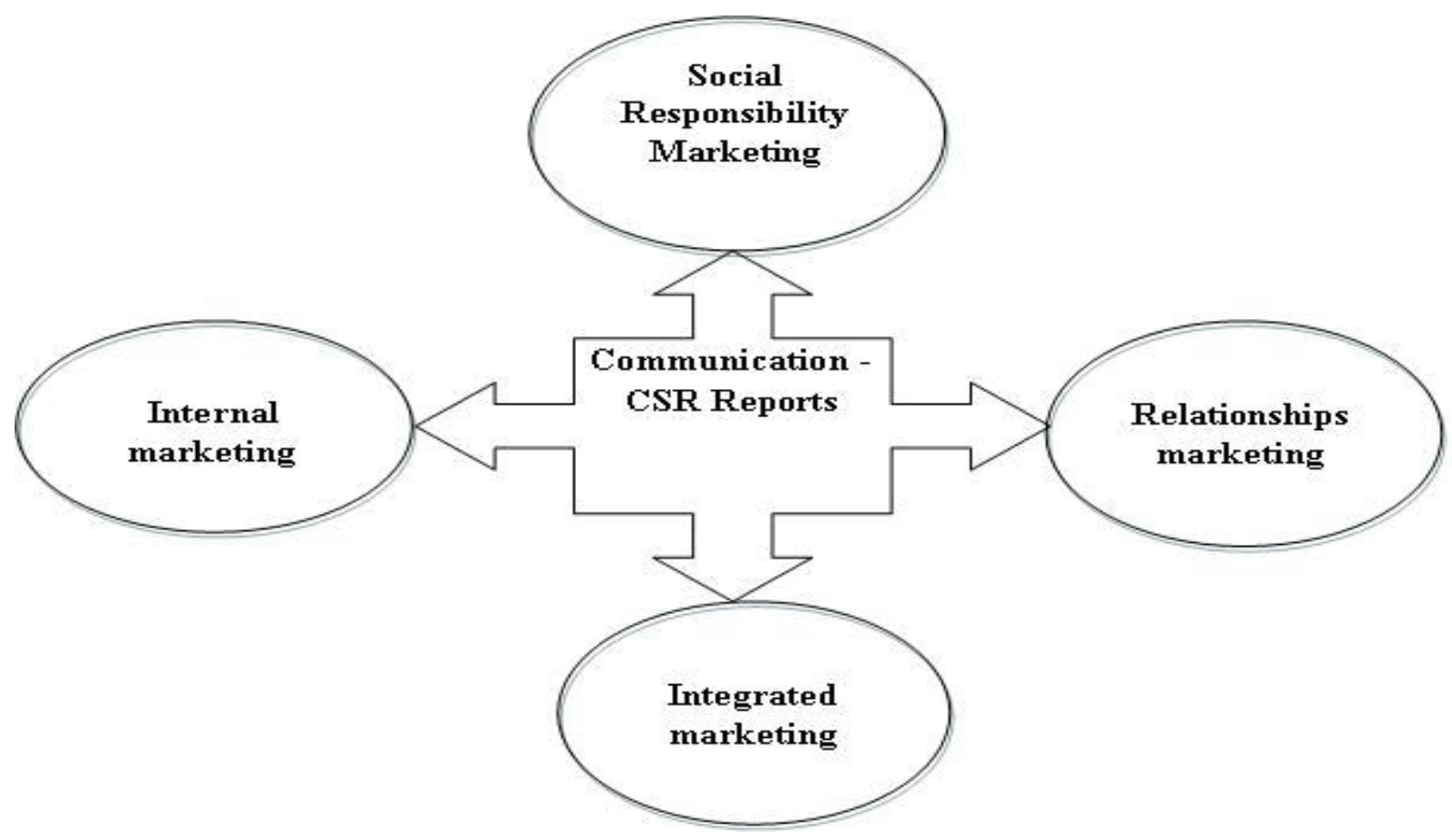

Figure 3. CSR reports in the context of a holistic marketing

Source: composed by authors

Meanwhile, G. Birth et al (2008: 184) emphasizes that due to CSR reporting the uniqueness of the product increases and companies can sell products at a higher price. R. Chomvilailuk and K. Butcher (2010) note that there is a positive relationship between CSR and brand value creation. Companies, who are aware how to integrate CSR reports in brand value creation processes, gain a clear competitive advantage. Consumers demand from companies for more than just place in the market a quality product at a low price, they are hoping that will match some social values of the organizations and consumer; and companies will contribute to community development (Ruiz, 2007).

H. Walker and N. Jones (2012: 15) argues that, in recent decades, there has been an increased interest in how CSR initiatives are implementing during supply chain development processes.

A. W. Sutantoputra (2009: 38) argues the benefits of CSR reporting by stating that CSR reports often contain information that is not included in the financial statements, but is extremely important in making business decisions. Such information is necessary in order to attract investors and new partners. G. Birth et al. (2008: 185) emphasize that CSR reporting often promotes a company's stock price or the growth of the amount of trading shares. In addition, it is noted those in recent years, there is growing interest in socially responsible investment. In other words, CSR reporting can provide for businesses easier access to capital.

D. O'Rourke (2004, p. 22) emphasizes that researches conducted in the United States, has found out that a third part of consumers avoid the use of products that have been produced in poor conditions. $86 \%$ of these respondents would be willing to pay more for a product if they knew that it produced under qualitative conditions. It was found out that $78 \%$ of the respondents would agree to pay $25 \%$ more for a garment, which is made by company, who guides social and environmental standards. According to I. Maignan (2001), past studies showed that consumers are willing to promote socially responsible business practices, however, there have not been described the companies' behavior which users can perceive as a significant to social responsibility. The survey conducted in United Kingdom revealed that $50 \%$ of respondents avoid buying or boycotting products produced by irresponsible behavior-rich companies. However, it was noticed that only a small percentage of respondents actually refused to buy the goods of socially irresponsible corporate. This phenomenon can exist because of the fact that consumers lack information about what social and environmental consequences could have the consumption of such products. 
Consumer perception and attitude affects their behavior. However, it should be noted that only the attitude is bad factor for predicting consumer behaviour. While some consumers, according to P. de Pelsmacker et al. (2005), do not buy products of unethically company, but mostly individuals collectively assess product characteristics when making consumption decisions. L. M. S. Ruiz (2007) and P. de Pelsmacker et al. (2005), O. Uusitalo and R. Oksanen (2004) highlighted that CSR activities are not the dominant criteria of consumer buying decisions. Price, quality, convenience and brand awareness is still the most important factors affecting consumption decisions and consumers continue to buy goods for personal rather than social reasons.

Summarizing the benefits of CSR reporting, it can be argued that the organizations which satisfy stakeholders' expectations, needs, and inform them of the action taken to meet these expectations, have greater success of the business, i.e. stability and profitability. Business success is one of the key objectives of marketing. Therefore, it is reasonable to argue that CSR reporting is one of the marketing tools.

It should be noted that companies which opted CSR reporting as one of the marketing tools may face with some problems in the preparation of these reports and integrating them in to the marketing process. R. Tewari (2011: 23) argues that it is possible to confront with a strong CSR communication risk than the businesses have no idea about the communication extent, ways and accents. Companies also may fail by choosing bad communication strategy. According to the author, companies, according to the chosen CSR communication strategy, can be divided into three groups:

- "Talk to talk" companies. Organizations which only make public announcement on the CSR, but in fact do not take real actions.

- "Walk the talk" companies. Organizations which take earlier announced social responsibility activities. The real actions complement to published information.

- "Talk the walk" companies. Organizations that primarily focuses on efforts to implement CSR activities; and only then inform the public about the company's contribution to value creation (Tewari, 2011: 23).

R. Tewari (2011: 23) notes that most of the organizations choose a strategy "just talk" or vice versa - absolutely not inform the public about the CSR practices. According to I. Pollach et al. (2012: 205), the company conveying CSR only to public relations campaign, i.e. applying a superficial rather than strategically, loses the opportunity to get maximum benefits. Reports must accurately disclose the actual company's actions and not rhetoric or biased information (Gill et al, 2008: 245). O. Idowu and B. A. Towler (2004) points out that sometimes instead of growing reputation, companies receive negative comments and anger; it could happen if there would be differences between in CSR reports declared values and the real action. However, those organizations who are fair to the stakeholders and avoid biased reporting achieve a greater reliability. Therefore, according to D. O'Rourke (2004: 25), enterprises when conducting CSR reports must understand the essential thing - in these reports should be stated essential and interesting information, the reports must be understandable, useful and to give the opportunity to stakeholders to compare given information with the others companies' CSR reports.

I. Maignan et al (2005: 966) in article "A Stakeholder Model for Implementing Social Responsibility in Marketing" provides an eight-step model (see Figure 4). This model explains how organizations can integrate CSR practices into the marketing process. According to R. E. Hinson and P. Kodua (2012: 333), only in the company's strategy integrated, unique and consistent with the company's activities CSR practice will be useful.

It should be noted that the authors of the model suggest using CSR reports in the three of the eight steps. In the fifth step, CSR reports help to assess the company's ongoing CSR practices. Obtained conclusions allow for the company objectively evaluate what additional initiatives should be taken. Very important step in the process of integration is CSR supporting, i.e. the seventh step. According to the authors of the model, CSR reports are becoming increasingly popular tool of public communication. CSR reports are applied at the last - eighth - step when identifying and assessing stakeholders' feedback response. This model is generalized by V. Juščius (2009: 267) statement that the dialogue with key stakeholders is crucial to the formation 
and implementation of CSR. M. Marais (2012: 226) complements this assertion stating that CSR communication is an essential element of CSR development between organizations.

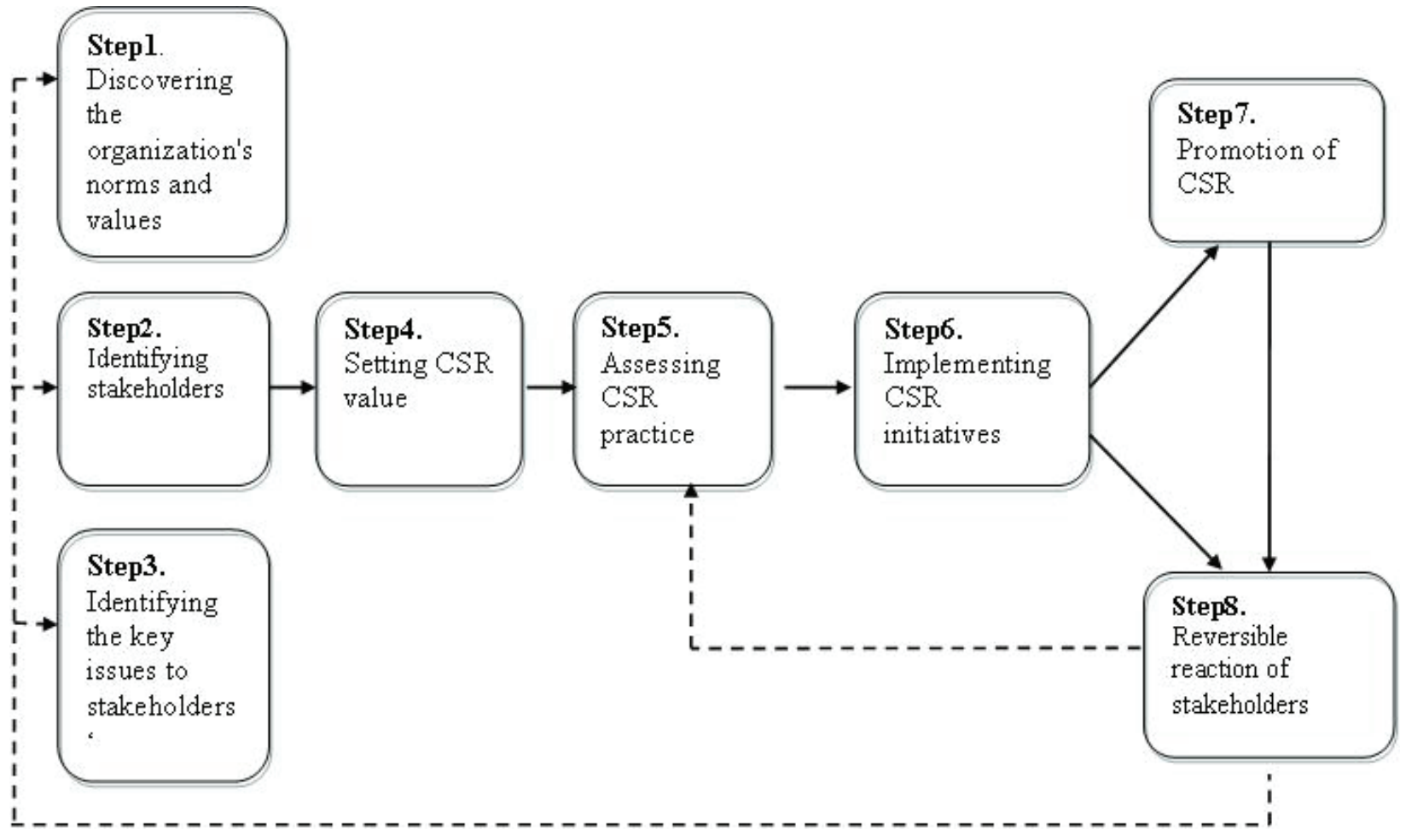

Figure 4. The model of integration business practice in to the marketing process

Source: Maignan et al., 2005: 966

D. O'Rourke (2004) argues that CSR reports can help to bring socially responsible companies together, i.e. create high-value supply chain. High value supply chain development minimizes the risk of profitability, help to maintain or even increase the market position, manage the problems as soon as they occur.

As a relationship marketing tool, CSR reports form the strong links between marketing participants, i.e. stakeholders' with which the company maintains a mutually beneficial relationship. Relationship marketing goal - an establishment of a unique and enduring relationship based marketing network. S. O. Idowu, B. A. Towler (2004: 424) stated, that one of the reasons for the application of CSR reporting is the ability to calm a few stakeholders groups, such as, for example, ecology, environment activists. In the case of relationship marketing, the leading role also is performed by communication. During communication process the company receives a reversible reaction. This is important information that helps to analyze the stakeholders' needs and identify gaps in the company's internal processes.

The goal of internal marketing - to attract and motivate employees to adequately serve to the stakeholders, and whom themselves are a group of stakeholders. According to G. Birth et al. (2008: 185), the company, through CSR communication as an internal marketing tool, has four objectives:

- To form a good opinion of the employees about the company. According to G. Birth et al. (2008: 185), the British Institute's Market and Opinion Research International study found out that $85 \%$ of employees involved in CSR initiatives, respond positively about the company. $65 \%$ of employees who were informed about the company's CSR policy positively evaluated the company.

- To promote employees' satisfaction and loyalty to the company. Employees are more likely to devote if company is socially responsible.

- To attract potential employees. "U.S. researches show that CSR can be a weapon in battles for talented workers" (Hildebrand et al, 2011: 1358). 
- To reduce employees' turnover. Employees who relate company with socially responsible behavior are less likely to leave the work place.

CSR reporting in many cases depend on the country or even the region where the company operates. "CSR reporting differences in the various states determined the economic situation, social, cultural and national differences" (Gill et al., 2008: 245). According to Y. Gao (2011: 267), Kenexa Research Institute after analyzing the CSR reports of Brazil, China, Germany, India, Britain and the U.S. companies, noted that attitude toward the employees differ. In CSR reports of Indian and Chinese companies the main focus is on elderly employees, meanwhile, in CSR reports of Germany, the UK and the U.S. companies the main focus is on young workers. It should be noted that, according to R. Othman and R. Ameer (2009: 301), in the case of voluntary CSR reporting the rule of "one model fits all" - is invalid.

It can be concluded that the companies who are incapable of linking CSR and marketing, can not get the maximum benefit from CSR activities. Literature analysis suggests that CSR reporting is becoming the main link of different holistic marketing programs, i.e. the tool of communication. As an integrated marketing tool, CSR increases the company's capabilities to create value. As a relationship marketing tool, CSR helps the organization to develop and manage relationships with its operating environment. Social responsibility of marketing is seeking to meet stakeholders' expectations in the implementation of the organization's goals. As a marketing tool, CSR reporting enables to attract and retain human capital. All of these marketing programs have a common element - communication. Thus, communication is a contact between CSR reporting and marketing, allowing to call CSR reports as a holistic marketing, covering a variety of marketing programs, instrument. It is necessary to emphasize that the maximum benefits companies can achieve only when CSR reporting is integrated into the company's strategy.

\section{Conclusions}

The periods of development of the CSR reporting can be divided into three phase. Only during the third phase, there can be the growing integration of social audit (assessment of social issues), environmental issues and certified standards into the companies' reports. First CSR reports were voluntary. Although the firsts CSR reports informed about social problems, but the integration of the CSR reporting requirements into the social legislation is the least developed. Belgium, the first in the world, established social accountability requirements in the legal system.

Although the firsts CSR reports were voluntary, in the absence of legislation, but today the companies are under the great pressure from the public to provide information on CSR activities. With the growing interest in CSR, companies also realize the benefits of CSR reporting. However, the benefits of CSR reporting depend on the company's contribution. Only responsibly and professionally prepared reports can act as a powerful marketing tool and a means of helping to adapt CSR practice in marketing processes.

Companies can receive negative feedback and comments instead of better reputation, higher brand value and so on, if differences between in CSR reports declared values and the real action occur. Fair to the stakeholders organizations achieve a greater reliability. Organizations during CSR reports preparation must realize one essential thing - CSR reports must be written in understandable manner; useful, interesting and essential information should be proposed to stakeholders; thus, stakeholders could compare given information with the CSR reports of the others companies' operating in the same industry.

Literature analysis suggests that CSR reporting is becoming the main link of different holistic marketing programs, i.e. the tool of communication. As an integrated marketing tool, CSR increases the company's capabilities to create value. As a relationship marketing tool, CSR helps to develop and manage relationships with its operating environment. Social responsibility of marketing is seeking to meet stakeholders' expectations in the implementation of the organization's goals. As a marketing tool, CSR reporting enables to attract and retain human capital. All of these marketing programs have a common element - communication. It is 
necessary to emphasize that the maximum benefits companies can achieve only when CSR reporting is integrated into the company's strategy.

\section{References}

Adams, A. C. (2008). A Commentary on: corporate social responsibility reporting and reputation risk management. Accounting, Auditing \& Accountability Journal, Vol. 21, No. 3, p. 365-370.

Barthorpe, S. (2010). Implementing corporate social responsibility in the UK construction industry. Property management, Vol. 28, No. 1, p. 4-17.

Birth, G., Illia, L., Laurati, F., Zamparini A. (2008). Communicating CSR: practices among Switserland's top 300 companies. Corporate Communication: An International Journal, Vol. 13, No. 2, p. 182-196.

Chomvilailuk, R., Butcher, K. (2010). Enhancing brand preference through corporate social responsibility initiatives in the Thai banking sector. Asia Pacific Journal of Marketing and Logistics,Vol. 22, No. 3, p. 397-418.

Crowther, D., Aras, G. (2008). Corporate Social Responsibility. UK: Ventus Publishing ApS.

Dagilienè, L., Gokienè, R. (2011). Valuation of social responsibility reports. Economics and Management, No. 16, p. 21-27.

Delbard, O. (2008). CSR legislation in France and the European regulatory paradox: an anglysis of EU CSR policy and sustainability reporting practice. Corporate governance, Vol. 8, No. 4, p. 397-405.

Douglas, A., Doris, J., Brian, J. (2004). Corporate social reporting in Irish financial institutions. The TQM Magazine, Vol. 16, No. 6, p. 387-395.

Gao, Y. (2009). Corporate social responsibility and consumers response: the missing linkage. Baltic Journal of Management, Vol. 4, No. 3, p. 269-287.

Gao, Y. (2011). CSR in an emerging country: a content anglysis of CSR reports of listed companies. Baltic Journal of Management, Vol. 6, No. 2, p. 263-291.

Gill, D. L., Dickinson, S. J., Scharly, A. (2008). Communicating sustainability. A web content anglysis of North American, Asian and Europe firms. Journal of Communication Management, Vol. 12, No. 3, p. 243-262.

Hildebrand, D., Sen, S., Bhattacharrya, C. B. (2011). Corporate Social responsibility: a corporate marketing perspective. European Journal of Marketing, Vol. 45, No. 9/10, p. 1353-1364.

Hinson, R. E., Kodua, P. (2012). Examinig the marketing-corporate social responsibility nexus. International Journal of Law and Management, Vol. 54, No. 5, p. 332-344.

Idowu, S. O., Towler, B. A. (2004). A comparative study of the contents of corporate social responsibility reports of UK companies. Management of Environmental Quality: An International Journal, Vol. 15, No. 4, p. 420-437.

Idowu, S. O., Papasolomou, I. (2007). Are the corporate social responsibility masters base on good intentions or false pretences? An empirical study of the motivations behind the issuing of CSR reports by UK companies. Corporate governance, Vol. 7, No. 2, p. 136-147.

Idowu, S. O. (2011). An exploratory study of the historical landscape of corporate social responsibility in the UK. Corporate governance, Vol. 11, No. 2, p. 149-160.

Jones, P., Comfort, D., Hillier, D. (2005). Corporate social responsibility and the UK's top ten retailers. International Journal of Retail \& Distribution Management, Vol. 33, No. 12, p. 882-892.

Jones, P., Comfort, D., Hillier, D. (2006). Reporting and reflecting on corporate social responsibility in the hospitality industry. A case study of pub operators in the UK. International Journal of Contemporary Hospitality Management, Vol. 18, No. 4, p. 329-340.

Jones, P., Comfort, D., Hillier, D. (2007). Marketing and corporate social responsibility within food stores. British food Journal, Vol. 109, No. 8, p. 582-593.

Juščius, V. (2009). Imonių socialinè atsakomybė ir organizacijų tapatumas šiuolaikinės ekonominės krizės kontekste. Ekonomika ir vadyba, Nr. 14, p. 264-271.

Maignan, I., Ferrell, O. C., Ferrell, L. (2005). A stakeholder model for implementing social responsibility in marketing. European Journal of Marketing, Vol. 39, No. 9/10, p. 956-977.

Maignan, I. (2001). Consumers' perceptions of corporate social responsibilities: a cross-cultural comparison. Journal of Business Ethics, Vol. 30, No. 1, p. 57-72.

Marais, M. (2012). CEO rhetorical strategies for corporate social responsibility (CSR). Society and business review, Vol. 7, No. 3, p. 223-243.

O'Connor, N. (2001). UK corporate reputation management: The role of public relations planning, research and evaluation in a new framework of company reporting. Journal of Communication Management, Vol. 6, No. 1, p. 53-63.

O'Rourke, D. (2004). Opportunities and obstacles for corporate social responsibility in developing countries. University of California. Website: < http://nature.berkeley.edu/orourke/PDF/CSR-Reporting.pdf>

Othman, R., Ameer, R. (2009). Corporate social and environmental reporting: Where are we heading? International Journal of Disclosure and Governance, Vol. 6, No. 4, p. 298-320.

Pelsmacker de P., Driesen, L., Rayp, G. (2005). Do consumers care about ethics? Willingness to pay for fair-trade coffee. The Journal of Consumer Affairs, Vol. 39, No. 2, p. 363-385. 
Pollach, I., Johansen, T. S., Nielsen, A. E., Thomsen, Ch. (2012). The integration of CSR into corporate communication in large European companies. Journal of Communication Management, Vol. 16, No. 2, p. 204-216.

Ruiz, L. M. S. (2007). "I Need You Too!" Corporate identity attractiveness for consumers and the role of social responsibility. Journal of Business Ethics, Vol. 71, No. 3, p. 245-260.

Samy, M., Odemilin, G., Bampton, R. (2010). Corporate social reponsibility: a strategy for sustainable business success. An analysis of 20 selected British companies. Corporate governance, Vol. 10, No. 2, p. $203-217$.

Sutantoputra, A. W. (2009). Social disclosure rating system for assessing firms' CSR reports. Corporate comunication: An International Journal, Vol. 14, No. 1, p. 34-48.

Sweeney, L., Coughlan, J. (2008). Do different industries report Corporate Social Responsibility differently? An investigation through the lens of stakeholders theory. Journal of marketing Communications, Vol. 14, No. 2, p. $113-124$.

Tewari, R. (2011). Communicating Corporate Social Responsibility in Annual Reports: A Comparative Study of Indian Companies\&Multi-National Corporations. Journal of Management \& Public Policy, Vol. 2, No. 2, p. $22-51$.

Uusitalo, O., Oksanen, R. (2004). Ethical consumerism: a view from Finland. International Journal of Consumer Studies, Vol. 28, No. 3, p. 214-221.

Žičkienè, S., Juozaitienè, L. (2013). Disclosure of environmental, social and governancen information using diverse reporting schemes. Socialiniai tyrimai, Vol. 31, No. 2, p. 24-36.

Walker, H., Jones, N. (2012). Sustainable supply chain management across the UK private sectors. Supply chain management: An International Journal, Vol. 17/1, p. 15-28.

\title{
IMONIU SOCIALINÉS ATSAKOMYBÉS ATASKAITU, KAIP RINKODAROS PRIEMONÉS, NAUDOS VERTINIMAS
}

\author{
Vytautas Juščius, Agné Šneiderienė, Julija Griauslytė \\ Klaipėdos universitetas (Lietuva)
}

Santrauka

Straipsnyje analizuojama ịmonių socialinės atsakomybės ataskaitų, kaip rinkodaros priemonės, Ł̇monèms teikiama nauda. Nagrinejjama ISA atskaitomybès evoliucija, susisteminti teoriniai ISA ataskaitu taikymo rinkodaroje aspektai. Straipsnyje akcentuojama, kad tenkindama suinteresuotu grupių lūkesčius, poreikius ir informuodama jas apie veiksmus, kurių imtasi šiems lūkesčiams patenkinti, organizacija turi gerokai daugiau galimybių užsitikrinti verslo sėkmę.

Verslo socialinės atsakomybės ataskaitos vis dažniau tampa tyrimų objektu išsivysčiusių užsienio šaliu mokslinejje literatūroje. Analizuojamas verslo socialinès atsakomybės ataskaitų taikymas, kuriant i̇monės reputaciją ir ịvaizdi (Adams, 2008), tenkinat suinteresuotu grupių poreikius, lūkesčius (Jones et al., 2007), tiriamas imonių socialinės atsakomybės ataskaitos naudojimas kuriant prekės ženklų vertę (O'Rourke, 2004). Kita vertus, esti akademinès visuomenès atstovų, kurie teigia, kad verslo socialinės atsakomybės veiklos publikavimas, viešinimas nebūtinai teigiamai veikia imones (Maignan 2001; Jones et al., 2006), suinteresuotoms grupèms pačioms nelabai reikia per daug informacijos apie verslo socialinę atsakomybę (Pelsmacker et al., 2005). Didžiausi laimèjimai analizuojant, tiriant verslo socialinès atsakomybès ataskaitas ir jų taikymo galimybes priklauso Didžiosios Britanijos akademinès visuomenès atstovams (O'Connor, 2001; Idowu, 2004, 2007, 2011; Jones, Comfort, Hillier, 2005, 2006, 2007; Crowther, 2008; ; Birth, 2008; Samy, Odemilin, Bampton; 2010; Barthorpe, 2010; Walker ir Jones, 2012). Aktualëjantis verslo socialinès atsakomybės ataskaitų vaidmuo rinkodaroje nepakankamai atsiskleidžia Lietuvos autorių darbuose. Deja, tyrimai šia tema buvo atliekami tik kitų tyrimo objektų kontekste. Šias ataskaitas savo darbuose nagrinejo tik keli Lietuvių autoriai: L. Dagilienė, R. Gokienė (2011), V. Juščius (2009), S. Žičkienė, L. Juozaitienė (2013).

Analizuojant mokslinę literatūrą (Tewari, 2011; Sutantoputra, 2008; Hildebrand et al, 2011; O'Connor, 2001; Maignan, 2005; Sweeney et al, 2008), galima pastebèti, kad ISA ataskaitos yra ne tik socialinès atsakomybès, bet ir integruotos, vidinès bei santykių rinkodaros priemonės. Integruotos rinkodaros atveju imonè, naudodama ISSA ataskaitas, gali padidinti galimybes sukurti vertę, informuoti apie ją ir pateikti suin- 
teresuotoms grupėms. İmonèms, kurios pasirinko İSA ataskaitų rengimą kaip vieną iš rinkodaros instrumentų, gali kilti problemų: per didele İSA komunikacijos rizika (kai verslas neturi supratimo apie komunikacijos mastą, būdus, akcentus); pasirinkta netinkama komunikacijos strategija. Anot I. Pollach et al. (2012: 205), imonès, nukreipiančios ISA tik i̇ viešujų ryšių kampanija, t. y. taikančios paviršutiniškai, o ne strategiškai, praranda galimybę gauti didžiausią naudą. ISA atskaitomybẻ dažnai priklauso nuo šalies ar net regiono, kuriame įmonė veikia. „ISA atskaitomybės skirtumus įvairiose šalyse lemia ekonominès situacijos, socialiniu sąlygų, kultūros ir nacionalinès teisès skirtumai““(Gill et al., 2008: 245).

Akcentuotina, kad i̇monès, nesugebančios susieti ISA ir rinkodaros, negali gauti maksimalios naudos iš ISA veiklos. ISA ataskaitos tampa skirtingų holistinès rinkodaros programų pagrindinès jungties, t. y. komunikacijos, priemone. Kaip integruotos rinkodaros priemoné, ISA padidina imonés galimybes sukurti vertę. Kaip santykių rinkodaros priemone, ISA padeda organizacijai kurti ir valdyti ryšius su ja supančia aplinka. Socialinės atsakomybės rinkodara siekiama patenkinti suinteresuotų grupių lūkesčius, igyvendinant organizacijos tikslus. Kaip vidinės rinkodaros priemonė, ISA atskaitomybė leidžia pritraukti ir išlaikyti žmogiškaji kapitalą. Visos šios rinkodaros programos turi bendrą elementą - komunikaciją, kuri yra İSA atskaitomybès ir rinkodaros sąlyčio taškas, leidžiantis İSA ataskaitas vadinti holistinès rinkodaros, apimančios i̇vairias rinkodaros programas, instrumentu.

PAGRINDINIAI ŽODŽIAI: ¿̇moniu socialinè atsakomybè, suinteresuotosios grupès, ¿̇moniu socialinès atsakomybès ataskaitos, holistine rinkodara, komunikacija.

JEL KLASIFIKACIJA: M140, M310 